International Journal of Agriculture, Environment and Bioresearch

Vol. 06, No. 01; 2021

ISSN: $2456-8643$

\title{
NORMATIVE METHOD FOR THE SUBSTANTIATION OF THE COMPOSITION AND QUANTITY OF MACHINES REQUIRED FOR 1000 HECTARES OF COTTON FIELD IN THE CONDITION OF UZBEKISTAN
}

\author{
Makhamad Tojalievich Toshboltaev ${ }^{1}$, Maoruf Rashidovich Djiyanov ${ }^{2}$, \\ Makhbuba Mamatkulova ${ }^{3}$, Iroda Emilyevna Tadjibekova ${ }^{4}$ and Nargiza Maminjanovna Temirkulova ${ }^{5}$ \\ ${ }^{1}$ Doctor of Technical Sciences, Professor, Deputy Director at Research Institute of Agricultural Mechanization, \\ Tashkent, Uzbekistan \\ ${ }^{2}$ Senior Teacher, Department of Agricultural Mechanization, Tashkent State Agrarian University, Tashkent, \\ Uzbekistan \\ ${ }^{3}$ Senior Teacher, Fergana branch of Tashkent Medicinal Institute, Fergana, Uzbekistan \\ ${ }^{4}$ Senior Teacher, Department of Agricultural Mechanization, Tashkent State Agrarian University, Tashkent, \\ Uzbekistan \\ ${ }^{5}$ Assistant, Department of Agricultural Mechanization, Tashkent State Agrarian University, Tashkent, Uzbekistan
}

https://doi.org/10.35410/IJAEB.2021.5603

\begin{abstract}
The article presents a normative method for substantiating the composition and quantity of tractors and agricultural machinery required for 1000 hectares of cotton in the soil and climatic conditions of the Republic of Uzbekistan. For the substantiation of the composition of machines (plough, disc harrow, seeder, cultivator, cotton harvester, etc.), modern equipments were selected to perform the agro-technical measures (ploughing, leveling, sowing, harvesting, etc.) identified in the technological map of cotton cultivation. In substantiating the required number of specific machine required for performing specific agricultural measure or practice per 1000 hectares, its productivity of one shift determined during testing, the duration of the shift, the number of shifts, the daily productivity, the duration of the agricultural measures and practices, the volume of seasonal work were used as arguments.
\end{abstract}

Keywords: Agricultural Measures, One Shift, Daily And Seasonal Productivity Of Machines, Number And Duration Of Shifts, Normative Number Per 1000 Hectares, Composition And Number Of Machines.

\section{INTRODUCTION}

In Uzbekistan, raw materials from cotton are mainly produced in cotton and textile clusters, and the processing of the harvested crop into finished products is expanding. To increase the potential and quality of the yield, the clusters should have agricultural machinery loop that performs all the operations listed in the technological map of cotton cultivation. If the types and numbers of machines do not meet the standards, some technological operations are not performed or not completed in the optimal time. When the number of machines exceeds the norm, their annual utilization coefficients (levels) decrease and storage costs increase. Therefore, the development of normative methods to substantiate the rational composition and quantity of 
the machine fleet, which should be on the balance of cotton and textile clusters, is an urgent scientific and practical issue.

The aim of research - is to develop a normative method for substantiating the rational composition and quantity of the machine fleet, which performs technological operations in cotton growing in optimal time in 1000 hectares of land of cotton-textile clusters in the soilclimatic conditions of Uzbekistan.

\section{MATERIALS AND METHODS}

The main mechanized technologies used in the cultivation of cotton in the soil and climatic conditions of Uzbekistan are as follows: land fertilization, ploughing, deep loosening, leveling, preparation for sowing, seeding, loosening the soil between the rows of cotton, chemical treatment against diseases and pests of cotton plants, defoliation of cotton before the cotton harvest, mechanical harvesting of cotton, delivery of harvested raw cotton to processing enterprises. These agricultural technologies are implemented using machine-tractor units (MTU) consisting of universal-mowing and mowing tractors, as well as of fertilizer machine, ploughs, loosening machine, levelers, harrows, mouldboard, drills, cultivators, sprayers, cotton harvester, tractor trailers. Based on the results of many years of experience in testing and operation of various cotton machines in the field, we recommend the following procedure for determining the composition and quantity of tractors and agricultural machinery required for 1000 hectares of field area $[1,2]$ :

1) $w_{c}$ value of the productivity of a tractor or machine of a specific model in 1 shift is obtained (in ha / h) from the protocols of the Center for Certification and Testing of Agricultural Machinery and Technologies;

2) according to the operative references received from the regional agricultural departments, a set of relevant numbers is compiled for the duration of 1 shift on ' $T_{c}$ ' (in hours) and the number of shifts used per day on ' $n_{c}$ ' in the implementation of appropriate agro-technical measures using a specific type of machine (MTU) by regions. By statistical processing of numbers their arithmetic mean values throughout the republic are determined;

3) machine productivity per day (in hectares) is calculated by this formulae:

$$
w_{l}=w_{c} T_{c} n_{c}
$$

4) the duration of specific agricultural measure season on ' $T_{M}$ ' is not defined by calendar time from the beginning of the season to its end, but from the busy, i.e stabilized and intensive time of the season. Because in busy and peak time of the season, all the machines of specific models in the balance sheet of clusters, farms, alternative and district "Agroservis MTP" and needed for this season practices, are fully involved in the work, their sudden breakdowns decrease and they begin to function stably. The values of $w_{c}, T_{c}$ and $n_{c}$ parameters, i.e. the value of $w_{l}$, are also timed and calculated by examiner-engineers in the same period.;

5) while-season $\left(T_{M}\right)$ work productivity of machine with $w_{l}$ daily productivity is calculated by this formulae: 
Vol. 06, No. 01; 2021

ISSN: $2456-8643$

$$
w_{M}=w_{l} T_{M}(\mathrm{ha})
$$

6) The total number of specific model machines required to implement a specific type of agro-technical measure in 1000 hectares of cotton is determined as follows:

$$
M_{T}=1000: w_{M} \text {. }
$$

The rules of operating machine-tractor fleet science were used to determine the number of machinery required for 1000 hectares of cotton fields.

\section{RESULTS AND DISCUSSION}

Calculating number of wheel-type utility tractors. Wheel-type utility tractors include to the group of tractors designed for operating general practices. They are used to plough the land, deep loosening, harrowing, chiseling and other soil tilling practices [3]. The peak period of autumn plowing in the republic makes $T_{M}=25$ days. If the duration of the season exceeds this period, the snowy and rainy days begin and the quality of the tillage deteriorates, it is even necessary to stop and leave it in the spring [4].

Magnum 8940 (240 h.p.), MX-255 (255 h.p.), MX-240 (282 h.p.) and K-701K (300 h.p.) model utility tractors with 240-300 horse power are considered as group-1 tractors. When these tractors are aggregated with "EuroOpal 5 4+1 N100", "Standart 7 plus 3+1", ПД-4-45, ПНЯ-4+1-45 two-tiered and LD-100, O'P-4/5-40 ploughs for general practices, their daily work productivity in the republic was equal to $w_{l}=14$. According to such aggregate (2), $w_{M}=14 \cdot 25=350$ ha land is ploughed during the season.

Using the formula (3) we determine the number of wheel-type utility tractors required for 1000 hectares of land:

$$
M_{T}=1000: 350=2,857 \text { pieces. }
$$

“ARION 630C" (150 h.p.), XT3-17221 (165 h.p.), T-150K (165 h.p.), "John Deere 6175M" (175 h.p.), "T-7060 NewHolland" (213 h.p.) and chained BT-150Д (150 h.p.), T-402.01 (150 h.p.), XT3-181 (180 h.p.) wheel-type utility tractors with $150 \leq N<220$ h.p.engine power are included to group- 2. Daily work productivity of aggregates made from these tractors and "EurOpal5 3+1 N100", ПЯ-3-35-2, ПЛН-4-35, ПЛН-5-35, "EurOpal5 2+1 N100" ploughs is found to be equal to the half of productivity of group-1 utility aggregates, that is, $w_{l}=7$ (14:2). In this case, seasonal productivity of the aggregate is equal to $w_{M}=7 \cdot 25=175$ ha, number of tractors required for operating in 1000 hectares equal to $M_{T}=5,714$ pieces (1000:175).

With horse power between $100 \leq N<150$ h.p. and with fixed engines, chained T-4A.01 (130 h.p.), ВТ-100 (130 h.p.), ДТ-75, ДТ-75М (95 h.p.) and and wheel-type utility tractors "NewHolland TD 5.110" (110 h.p.), "John Deere 6110B" (110 h.p.), “John Deere 6135B" (135 h.p.), "T-6072 NewHolland" (140 h.p.), "Belarus 1523" (148 h.p.), "ARION 630C" (150 h.p.) "Belarus" 1221.2 (130 h.p.), "AXOS 340C" (100 h.p.), MX-135 (140 h.p.), MX-140 (142 h.p.) are included to the $3^{\text {rd }}$ group of tractors. When these tractors are aggregated with ПНО-3-35, ПН-3-30, ПНЯ-3-35, ПЯ-3-35, ПД-3-35 type ploughs, their daily work productivity was found 
Vol. 06, No. 01; 2021

ISSN: $2456-8643$

to be $\frac{1}{3}$ part of work productivity of the $1^{\text {st }}$ group utility tractor aggregate, i.e equal to $w_{1}=4,666$ ha (14:3). Seasonal work productivity of this propellent unit: $w_{M}=116,65$ ha $(25 \cdot 4,666)$. The number of such tractors needed for 1000 ha crop field: $M_{T}=8,572(1000: 116,65)$.

Calculating number of row crop tractors. Row crop tractors such as TT3-811, TT3-100HC, "AXOS 340C", MT3-80X, TT3-80.11, TT3-60.11 and TT3-100K11 are designed for all mechanized farm activities in cotton cultivation, harvesting, as well as, cultivation and caring for other agricultural intercrops and their harvesting practices [3]. The number of row crop tractors is determined by the number of cultivators used for processing interrows of cotton plants: in the fields where the width of inter-rows is $90 \mathrm{~cm}$, an average seasonal work productivity of cultivator was found to be $w_{M}=75$ ha from the first processing to the fifth processing. Thus, $M_{T}$ $=13,3$ pieces of cultivator and the same number of row crop tractors are required for cotton interrow processing in 1000 hectares; when inter-row spacing is 60 and $70 \mathrm{~cm}$, then: $w_{M}=50$ ha, $M_{T}=20$ pieces.

Defoliation in cotton fields and pest control measures are performed with the help of sprayers mounted on row crop tractors. Seasonal work productivity of one preparation sprayer is equal to $w_{M}=250$ ha. The number of needed tractors for this is $M_{T}=4$ pieces.

To perform loading-unloading practices, it was proven in practice that three row crop tractors are required for 1000 hectares of cotton crop [1].

Calculating number of tractor trailers. Tractor trailers such as 2ПТС-4-793A (modifications 2ПТС-4-793А-01, 2ПТС-793А-03), 2ПТС-4-887 models are chosen by two pieces for universal row crop tractors TT3-60.10, TT3-80.10, TT3-100K10, MT3-80, MT3-82. Required number of such tractors for 1000 hectares is 12 pieces (the 3rd line of table). Accordingly, required number of tractor trailers equal to $M_{T}=24$ pieces.

Calculating number of disc harrow. Average shift productivity of disc harrows such as "Rubin 9/3001", “КD-3000”, БДТ-3,0 and ТДБ-3/5 models is: $w_{c}=(1,7+2,6): 2=2,15$ ha/hour. Daily work productivity: $w_{l}=w_{c} \cdot 10=2,15 \cdot 10=21,5$ ha. Seasonal land tilling duration with disc harrow is: $T_{M}=10$ days. Thus, $w_{M}=T_{M} w_{l}=10 \cdot 21,5=215$ ha and $T_{M}=1000: 215=4,651$ pieces.

Calculating number of seed drills. In the balance sheet of clusters, farms, "Agroservice MTP" and alternative MTPs, there are 4-row mechanic seed drills CTX-4 (M=60 cm inter-row), C4X4A, СЧХ-4Б, SChX-4B (M = $90 \mathrm{~cm}), \mathrm{CXY}-4(\mathrm{M}=60,70,90 \mathrm{~cm}), \mathrm{CMX}-4(\mathrm{M}=60,90 \mathrm{~cm})$ to sow fuzzy seeds and 4-and 8-row pneumatic seed drills "Planter-3M", "Planter-4M", "PlanterD4", "Case-1200" $(\mathrm{M}=60,76,90 \mathrm{~cm})$ to plant naked seeds [5, pp. 375-391]. The duration of seed sowing period in our republic makes $T_{M}=10$ days. Seasonal work productivity $w_{M}$ of seeders are: in 8-row pneumatic seed drill "Case-1200" for 60, 76 and $90 \mathrm{~cm}$ inter-row work is $350 \mathrm{ha}$; in 4-row mechanic seed drill for $60 \mathrm{~cm}$ inter-row work - $90 \mathrm{ha}$, for $90 \mathrm{~cm}$ inter-row work - 120 ha. Number of specific model seed drills required for 1000 hectares is $M_{T}=2,857$ (1000:350), 8,333 (1000:120) and 11,111 (1000:90) pieces. 
Calculating number of cotton topping device. For cutting the growing shoot tips of cotton plant, the farmers are using available ЧХУ-4A devices and РChM-4Б model devices produced by "Aggregate" plant [6]. These devices are mounted on front frame of cotton cultivator. This means that the more cotton cultivators there are in the cluster, the more topping devices there should be. For 1000 hectares of $90 \mathrm{~cm}$ inter-rows 13,3 pieces of topping device is required, for $60 \mathrm{~cm}$ inter-rows -20 pieces. Topping device mounted cultivators are recommended to be aggregated with TT3 $100 \mathrm{~K} .11$ or TT3 80.11 tractors.

Calculating number of sprayers. Fan sprayers VP-1, VP-11B, OBX-600, OBX-28A are used for feeding cotton and grain crops from the leaves (suspension spraying), disease and pest control, defoliation of cotton fields, chemical treatment of orchards and vineyards. Boom sprayers ОШУ1-200, ОШУ-50, ОПШХ-12/15 are used for spraying suspensions on row crops, chemicals against their diseases and pests, and defoliating cotton plants [7].

Annual work productivity of OBX-600 fan sprayer, when calculated considering all aforementioned agro-techical practices, made 250 ha as proven in practice. This means, if $W_{M}=$ 250, then $M_{T}=1000: 250=4$ pieces.

Calculating number of cotton harvesters. At present, double-row vertical-spindle MX-1.8 cotton harvesters are being produced in the country, designed to pick cotton grown in areas with a row spacing of $90 \mathrm{~cm}$ by semi-aggregated with TTZ-811 tractor [8].

In recent years, in all cotton fields of the country, harvesting is carried out after the defoliation of cotton when at least $90 \%$ of the bolls are opened. At the peak of the harvest, the opening rate of cotton bolls reaches $95-98 \%$. The cotton harvest season in the country is coming to an end in just 15 days. Therefore, we also assume that harvest season duration is $\mathrm{TM}=15$ days.

The results of many years of experience in the field operation and testing of two-row verticalspindle cotton pickers have shown that their daily work productivity is around 4-6 hectares [9]. For now, we consider that it is expedient to take the daily productivity of the machine equal to $w_{1}$ $=4$ ha.

Then the seasonal work productivity of machine makes $w_{M}=T_{M} w_{l}=15 \cdot 4=60$ ha. In order to pick the cotton of 1000 ha area within 15 days, 16,66 pieces (1000:60) machines are required.

In cotton harvesting period of 2020, the average seasonal productivity of CE-220 double-row horizontal spindle cotton harvesters per hectare was 100 hectares. Their number for 1000 hectares is $M_{T}=10$ pieces $(1000: 100)$.

The numbers of universal row crop tractors, levelers, deep cultivators, fertilizer spreaders, ploughs, tooth harrows, chisel cultivators and cotton cultivators were calculated in the same order and included in the table. 
Table 1.Calculation norms of machines required for 1000 hectares of cotton fields

\begin{tabular}{|c|c|c|c|c|c|}
\hline № & Machines & $\begin{array}{l}\text { Duration of } \\
\text { season } \\
T_{M}, \text { day }\end{array}$ & $\begin{array}{l}\text { Daily } \\
\text { productivity } \\
\text { of machine } \\
w_{1}, \text { ha }\end{array}$ & $\begin{array}{l}\text { Seasonal } \\
\text { productivity } \\
\text { of machine } \\
w_{\cdot m}, \text { ha }\end{array}$ & $\begin{array}{l}\text { Number } \\
\text { required } \\
\text { for } \quad 1000 \\
\text { hectares } \\
M_{T} \text {, pieces }\end{array}$ \\
\hline $\begin{array}{l}1 . \\
1.1 .\end{array}$ & $\begin{array}{l}\text { Utility wheel-type tractors: } \\
\text { Magnum } 8940, \text { MX-255, } \\
\text { MX-240, К-701К type }\end{array}$ & 25 & 14 & 350 & 2,857 \\
\hline 1.2 . & $\begin{array}{l}\text { "ARION 630C", "John Deere } \\
\text { 6175M", "T-7060 New } \\
\text { Holland", BT-150Д, T-402.01, } \\
\text { T-150K, ХT3-17221, XT3-181 } \\
\text { type }\end{array}$ & 25 & 7 & 175 & 5,714 \\
\hline 1.3 . & $\begin{array}{l}\text { ДТ-75, ДТ-75М, АХOS } 340, \\
\text { Belarus } 1221.2, \text { T-4A.01, BT- } \\
\text { 100, MX-135, MX-140, "New } \\
\text { Holland TD5.110", "John } \\
\text { Deere 6110B", "ARION } \\
\text { 630C", "AXOS 340C" type }\end{array}$ & 25 & 4,666 & 116,65 & 8,572 \\
\hline 2. & $\begin{array}{l}\text { Row crop tractors with } 3 \\
\text { wheels } \\
\text { processing: TT3-811, TT3- } \\
\text { 100HC, "AXOS 340C", MT3- } \\
\text { 80X, TT3-80.11, TT3-60.11, } \\
\text { TT3-100K11 }\end{array}$ & & & & \\
\hline 2.1 . & For $90 \mathrm{~cm}$ row spacing & & & 75 & 13,3 \\
\hline 2.2 . & For $60,70,76 \mathrm{~cm}$ row spacing & & & 50 & 20 \\
\hline 2.3 . & For defoliation and pest control & & & 250 & 4 \\
\hline 2.4 . & $\begin{array}{ll}\text { For } & \text { loading-unloading } \\
\text { practices }\end{array}$ & & & & 3 \\
\hline 3. & \begin{tabular}{ll}
\multicolumn{3}{l}{ Universal row crop tractors: LS } \\
"U62", TT3-812, "New \\
Holland TD5.110", "John \\
Deere 6110B", MT3-82, TT3- \\
60.10, TT3-80.10, \\
100K10, MT3-80
\end{tabular} & & & & 12 \\
\hline 4. & $\begin{array}{l}\text { Long base levelers: ПА-3, П- } \\
4 \mathrm{~A}, \Pi-2,8 \mathrm{~A}\end{array}$ & 20 & 12 & 240 & 4,166 \\
\hline 5. & $\begin{array}{l}\text { Deep loosening cultivators: } \\
\text { ГР-270, ГР-370, ГРХ-2-50, } \\
\text { ГРП-3/5, ГНУ-1МС }\end{array}$ & 25 & 14 & 350 & 2,857 \\
\hline 6. & Mineral fertilizer spreading & 20 & 13 & 260 & 3,846 \\
\hline
\end{tabular}


International Journal of Agriculture, Environment and Bioresearch

Vol. 06, No. 01; 2021

ISSN: $2456-8643$

\begin{tabular}{|c|c|c|c|c|c|}
\hline № & Machines & $\begin{array}{l}\text { Duration of } \\
\text { season } \\
T_{M} \text {, day }\end{array}$ & $\begin{array}{l}\text { Daily } \\
\text { productivity } \\
\text { of machine } \\
w_{1}, \text { ha }\end{array}$ & $\begin{array}{l}\text { Seasonal } \\
\text { productivity } \\
\text { of machine } \\
w_{M}, \text { ha }\end{array}$ & $\begin{array}{l}\text { Number } \\
\text { required } \\
\text { for } 1000 \\
\text { hectares } \\
M_{T} \text {, pieces }\end{array}$ \\
\hline & $\begin{array}{l}\text { machines: GS2-600, HPУ-0,5, } \\
\text { PMУ-0,5M, РMУ-0,75, МВУ- } \\
\text { 0,5А, 1РМГ-4, } \\
\text { 4Б } \\
\end{array}$ & & & & \\
\hline 7. & $\begin{array}{l}\text { Local fertilizer spreading } \\
\text { machines: POУ-6, РТП-5 }\end{array}$ & 20 & 5 & 100 & 10 \\
\hline 8. & $\begin{array}{l}\text { Tractor trailers: } 2 \text { 2ПC-4-793A, } \\
\text { 2ПТС-4-793А-01, 2ПТС- } \\
\text { 793А-03, 2ПТС-4-887 }\end{array}$ & & & & $\begin{array}{l}24 \text { (2 pieces } \\
\text { for one } \\
\text { universal } \\
\text { row crop } \\
\text { tractor) }\end{array}$ \\
\hline $\begin{array}{l}9 . \\
9.1 .\end{array}$ & $\begin{array}{l}\text { Ploughs: } \\
\text { For tractors of Magnum 8940, } \\
\text { MX-255, MX-240, К-701К } \\
\text { type: "EuroOpal5 4+1 N100", } \\
\text { "Standart 7plus 3+1", ПНЯ- } \\
\text { 4+1-45, ПД-4-45, О'Р-4/5-40 } \\
\text { ВТ-150Д, Т-402.01, Т-150К }\end{array}$ & 25 & 14 & 350 & 2,857 \\
\hline 9.2 & $\begin{array}{l}\text { For tractors of XT3-17221, } \\
\text { ХT3-181 type: "EurOpal5 3+1 } \\
\text { N100", LD-100, ПН-4-35, } \\
\text { ПЛН-5-35, }\end{array}$ & 25 & 7 & 175 & 5,714 \\
\hline 9.3 & $\begin{array}{l}\text { For tractors of "Т-6072 New } \\
\text { Holland", "ARION 630С", } \\
\text { "AXOS 340C", ДТ-75, ДТ- } \\
\text { 75М, AXOS 340, Belarus } \\
\text { 1221.2, Т-4A.01, ВТ-150, MX- } \\
\text { 135, MX-140 type: ПНЯ-3-35 } \\
\text { ПЯ-3-35, ПЛН-4-35, ПН-3-35, } \\
\text { ПН-2-35 }\end{array}$ & 25 & 4,666 & 116,65 & 8,572 \\
\hline 10. & $\begin{array}{l}\text { Tooth harrows: Б3СС-1,0; } \\
\text { Б3TC-1,0; Б3ТХ-1,0 }\end{array}$ & 10 & 100 & 1000 & $\begin{array}{l}1,0 \text { (a set of } \\
\text { harrows } \\
\text { consisting } \\
\text { of } 14 \text { units) }\end{array}$ \\
\hline 11. & $\begin{array}{l}\text { Disc harrows: "Rubin 9/3001", } \\
\text { "KD-3000", БДТ-3,0; ТДБ-3/5 }\end{array}$ & 10 & 21,5 & 215 & 4,651 \\
\hline 12. & \begin{tabular}{|l|l|} 
Chisel-cultivator: "Karat \\
9/300", ЧКУ-4A type
\end{tabular} & 10 & 20 & 200 & 5 \\
\hline 13. & Seed drills: & & & & \\
\hline
\end{tabular}


Vol. 06, No. 01; 2021

ISSN: $2456-8643$

\begin{tabular}{|c|c|c|c|c|c|}
\hline № & Machines & $\begin{array}{l}\text { Duration of } \\
\text { season } \\
T_{M} \text {, day }\end{array}$ & $\begin{array}{l}\text { Daily } \\
\text { productivity } \\
\text { of machine } \\
w_{1}, \text { ha }\end{array}$ & $\begin{array}{l}\text { Seasonal } \\
\text { productivity } \\
\text { of machine } \\
w_{m}, \text { ha }\end{array}$ & $\begin{array}{l}\text { Number } \\
\text { required } \\
\text { for } \quad 1000 \\
\text { hectares } \\
M_{T} \text {, pieces } \\
\end{array}$ \\
\hline \multirow[t]{2}{*}{13.1} & $\begin{array}{l}\text { 4-row mechanic seed drills: } \\
\text { For } 60 \mathrm{~cm} \text { row spacing: CTX- } \\
\text { 4, CXY-4, CMX-4 }\end{array}$ & 10 & 9 & 90 & 11,111 \\
\hline & $\begin{array}{l}\text { For } 90 \mathrm{~cm} \text { row spacing: CЧX- } \\
4 \mathrm{~A}, \mathrm{C} X-4 Б \text {, CXУ-4, CMX-4 }\end{array}$ & 10 & 12 & 120 & 8,333 \\
\hline 13.2 . & $\begin{array}{l}\text { 8-row pneumatic seed drills: } \\
\text { "Case-1200" type }\end{array}$ & 10 & 35 & 350 & 2,857 \\
\hline $\begin{array}{l}14 . \\
14.1 .\end{array}$ & $\begin{array}{l}\text { Cotton cultivators: } \\
\text { For } 90 \mathrm{~cm} \text { row spacing: KXУ- } \\
\text { 4, КРТ-4, KPX-3,6 }\end{array}$ & & & 75 & 13,3 \\
\hline 14.2. & $\begin{array}{l}\text { For } 60,70,76 \mathrm{~cm} \text { row spacing: } \\
\text { КХУ }-4, \text { КРX-4 }\end{array}$ & & & 50 & 20 \\
\hline $\begin{array}{l}15 . \\
15.1 .\end{array}$ & $\begin{array}{l}\text { Cotton topping machines: } \\
\text { PChM-4Б } \\
\text { For } 90 \mathrm{~cm} \text { row spacing }\end{array}$ & & & & 13,3 \\
\hline 15.2 . & For $60 \mathrm{~cm}$ row spacing & & & & 20 \\
\hline 16. & $\begin{array}{lr}\text { Sprayers: } & \text { VP-1, } \\
\text { OШУ-50, } & \text { ОВШХ-600, } \\
\text { ОШУ-1-200 } & \\
\end{array}$ & & & 250 & 4 \\
\hline 17. & $\begin{array}{l}\text { Double-row spindle cotton } \\
\text { harvesters: picking device with } \\
\text { series and spindle in } \\
\text { component is mounted on }\end{array}$ & & & & \\
\hline 17.1. & $\begin{array}{l}\text { MX-1,8 type machine: } \\
\text { On hectares } \\
\text { On tons }\end{array}$ & $\begin{array}{l}15 \\
15\end{array}$ & $\begin{array}{l}4 \\
10,88 \\
\end{array}$ & $\begin{array}{l}60 \\
163,2 \\
\end{array}$ & 16,66 \\
\hline 17.2. & $\begin{array}{l}\text { Boll intensive treating picking } \\
\text { device equipped with spindle } \\
\text { in component is mounted on } \\
\text { machine: } \\
\text { On hectares } \\
\text { On tons }\end{array}$ & $\begin{array}{l}15 \\
15\end{array}$ & $\begin{array}{l}4 \\
11,62\end{array}$ & $\begin{array}{l}60 \\
174,4\end{array}$ & 16,66 \\
\hline 17.3. & $\begin{array}{l}\text { Double-row horizontal spindle } \\
\text { CE-220 cotton harvester: } \\
\text { On hectares } \\
\text { On tons }\end{array}$ & $\begin{array}{l}15 \\
15 \\
\end{array}$ & $\begin{array}{l}6,66 \\
20\end{array}$ & $\begin{array}{l}100 \\
300\end{array}$ & 10 \\
\hline
\end{tabular}




\section{CONCLUSIONS}

By using the criteria given in the table, it is possible to determine the composition and amount of equipments required for the production of any agro-cluster and farm. For example, calculation norms of "Bukhara AgroKlaster" LLC technical park with cotton fields of 47264 ha: for 1.1-row 135 pcs, for 1.2-row 270 pcs, 1.3-row 405 pcs, 2.1-row 629 pcs, 2.2-row 945 pcs, 2.3-row 189 pcs, 2.4-row 142 pcs, 3-row 567 pcs, 4-row 197 pcs, 5-row 135 pcs, 6-row 181 pcs, 7-row 473 pcs, 8-row 1134 pcs, 9.1-row 135 pcs, 9.2-row 270 pcs, 9.3-row 405 pcs, 10-row 47 pcs, 11-row 220 pcs, 12-row 236 pcs, 13.1-row 525 pcs and 394 pcs, 13.2-row 135 pcs, 14.1-row 629 pcs, 14.2-row 945 pcs, 15.1-row 629 pcs, 15.2-row 945 pcs, 16-row 189 pcs, 17.1 and 17.2-rows 787 pcs, 17.3-row 473 pcs.

The problem of calculating the demand of agricultural clusters for agricultural machinery is to determine the composition of the machine-tractor fleet in such a way as to ensure the quality and high productivity of mechanized agricultural practices, minimal labor and operating costs per unit of work.

\section{REFERENCES}

[1] Toshboltaev M., Azizov Sh. Calculation of the composition and number of equipment required for farms and machine-tractor fleets. (Monograph) - Tashkent: "Fan va tehnologiya", 2014. $185 \mathrm{p}$.

[2] Toshboltaev M., Azizov Sh. Determining the land area of the model farms specializing in cotton growing, the composition and quantity of the necessary equipments by the criteria of seasonal productivity of the cotton harvesting machine // Creating resource-saving agricultural machinery and increasing the efficiency of their use: Collection of scientific articles of the Republican scientific-practical conference. - Gulbahor: AMERI. - 2014. pp. 337-342.

[3] Tulanov I., Kambarov B., Mirsaidov R. Tractors. "Cotton growing bulletin ”. - Tashkent: "Fan va tehnologiya", 2016. pp. 309-334.

[4] Hasanova F. Preparation of land for sowing. "Cotton growing bulletin". - Tashkent: "Fan va tehnologiya", 2016. pp. 223-225.

[5] Korakhonov A. Seed drill and herbicide sprayers. "Cotton growing bulletin". - Tashkent: "Fan va tehnologiya", 2016. pp. 375-391.

[6] Korakhonov A. Row crop and topping machines. "Cotton growing bulletin". - Tashkent: "Fan va tehnologiya", 2016. pp. 391-408.

[7] Toshboltaev M. Machines for disease and pest control and cotton defoliation. "Cotton growing bulletin". - Tashkent: "Fan va tehnologiya", 2016. pp. 418-425.

[8] Toshboltaev M. Cotton harvesters. "Cotton growing bulletin". - Tashkent: "Fan va texnologiya", 2016. pp. 425-446.

[9] Maintenance and efficient operation of cotton and grain machines: Manual (amended, completed 2nd edition) / editor-in-chief M. Toshboltaev. - Tashkent: Fan, 2012. pp. 121122. 